\title{
\begin{tabular}{l} 
Journal of Educational \\
$\begin{array}{l}\text { Journal of Educational Chemistry (1 (2), 2019, 92-106) } \\
\text { Website: } \text { http://www.journal.walisongo.ac.id/index.php/jec } \\
\text { Chemistry }\end{array}$ \\
$\begin{array}{l}\text { ISSN 2715-3029 (p) 2685-4880 (e) } \\
\text { DOI: } 10.21580 / \text { jec.2019.1.2.4382 }\end{array}$ \\
\hline
\end{tabular}
}

\section{Pengembangan Modul Kimia Socio-Scientific Issues (SSI) Materi Reaksi Reduksi Oksidasi}

\author{
Sofiana ${ }^{1}$, Teguh Wibowo ${ }^{2}$ \\ ${ }^{1}$ Madrasah Al-Irsyad Gajah Demak \\ 2Pendidikan Kimia Universitas Islam Negeri Walisongo Semarang \\ 1E-mail: sofieana155@gmail.com
}

\begin{abstract}
This developmental research motivated by learning difficulties in the redox material by students due to the limited number of teaching materials that can be used independently, the lack of variations in teaching materials used by teachers, and the low motivation of students to learn because they consider chemistry subjects that are difficult, and not directly related to life, specifically redox material. This is indicated by the presence of 58.9\% of students who state the redox material is difficult. Teaching materials that provide opportunities for students to learn according to their individual speed are modules. Purpose of this study is to produce a module that contains contextual learning with a socio-scientific issues approach. This developmental research use ADDIE (Analyze, Design, Develop, Implement, Evaluate) development model. Subjects of this developmental research were 9 students of class X MIA 2 MA Al-Irsyad Gajah. Results of the module quality assessment conducted by material expert validator were $84.60 \%$ with a very valid category. Evaluation of media expert validator was $91.00 \%$ with a very valid category, and students' response was 80.69\%. While the average score for the module readability test was $68.88 \%$ with the high readability category. These results indicate that the module developed is feasible to use and implemented in large classes.
\end{abstract}

Keywords: module teaching materials, socio-scientific issues (SSI), oxidation reduction reactions, ADDIE

92

Copyright (C) 2019 JEC | ISSN 2715-3029 (p) 2685-4880 (e)

Volume 1, Nomor 2, 2019 


\begin{abstract}
Abstrak
Penelitian pengembangan ini dilatarbelakangi oleh kesulitan belajar pada materi reaksi reduksi oksidasi yang dialami peserta didik akibat terbatasnya jumlah bahan ajar yang dapat digunakan secara mandiri, kurangnya variasi bahan ajar yang digunakan guru, dan rendahnya motivasi belajar peserta didik karena menganggap mata pelajaran kimia adalah mata pelajaran yang sulit, dan tidak berkaitan langsung dengan kehidupan, khususnya materi reaksi reduksi oksidasi. Hal ini ditunjukkan oleh adanya $58,9 \%$ peserta didik yang menyatakan materi reaksi reduksi oksidasi adalah materi yang sulit. Bahan ajar yang memberikan kesempatan bagi peserta didik untuk belajar menurut kecepatan masing-masing adalah modul. Tujuan penelitian ini adalah untuk menghasilkan modul yang memuat pembelajaran kontekstual dengan pendekatan socio-scientific issues (SSI). Model pengembangan yang digunakan dalam penelitian ini adalah model pengembangan ADDIE (Analyze, Design, Develop, Implement, Evaluate). Subjek penelitian pengembangan ini adalah 9 peserta didik kelas X MIA 2 MA Al-Irsyad Gajah. Hasil penilaian kualitas modul yang dilakukan oleh validator ahli materi diperoleh sebesar 84,60\% dengan kategori sangat valid. Penilaian validator ahli media sebesar 91,00\% dengan kategori sangat valid, dan respon peserta didik sebesar $80,69 \%$. Sedangkan rata-rata skor untuk uji keterbacaan modul sebesar 68,88\% dengan kategori keterbacaan tinggi. Hasil tersebut menunjukkan bahwa modul yang dikembangkan layak digunakan dan diimplementasikan pada kelas besar.
\end{abstract}

Kata Kunci: bahan ajar modul, socio-scientific issues (SSI), reaksi reduksi oksidasi, ADDIE

\title{
Pendahuluan
}

Media pembelajaran memiliki peran penting dalam usaha mencapai hasil belajar peserta didik secara optimal. Tidak cukup hanya dalam aspek pengetahuan, seiring dengan berkembangnya jaman peserta didik dituntut untuk bisa mengembangkan kemampuan berpikir kritis dan kreatif melalui proses pembelajaran (Rahmawati.dkk, 2018). Akan tetapi masih sedikit bahan ajar yang dirancang untuk menstimulasi perkembangan kemampuan berpikir kritis dan kreatif peserta didik. oleh karena itu dibutuhkan bahan ajar yang dirancang untuk menstimulasi kemampuan peserta didik dalam mengkonstruksi pengetahuannya secara mandiri. Salah satu bahan ajar yang dapat digunakan secara mandiri oleh peserta didik adalah modul.

Modul merupakan bahan ajar yang dapat memberikan kesempatan bagi peserta didik untuk belajar menurut kecepatan masingmasing. Selain itu modul juga mendukung peserta didik untuk mengenal kelebihan dan memperbaiki kelemahan dari peserta didik melalui pengulangan pada bagian materi yang belum dikuasai (Erifal, 2010:3). Direktorat Tenaga Kependidikan (2008) menjelaskan bahwa modul adalah salah satu bentuk bahan ajar yang disusun dengan utuh dan sistematis. Fungsi modul adalah sebagai buku pendamping 
peserta didik yang mampu mendorong peserta didik untuk menyelesaikan dan mencapai materi pembelajaranya, serta dapat memaksimalkan kemampuan belajar peserta didik secara mandiri.

Hasil obervasi dan wawancara peneliti dengan guru kimia di MA Al-Irsyad Gajah, diketahui bahwa jumlah bahan ajar kimia berupa buku pendamping peserta didik masih terbatas. Hal ini menyebabkan peserta didik kesulitan untuk belajar secara mandiri, akibatnya keterampilan peserta didik dalam mengkonstruksi pengetahuan secara mandiri kurang berkembang. Peserta didik mengaku bahwa dalam buku pelajaran kimia yang mereka gunakan hanya memuat secara singkat contohcontoh penerapan ilmu kimia yang dipelajari dan belum memuat pembelajaran yang mengaitkan materi dengan konteks dunia nyata atau permasalahan-permasalahan yang mereka hadapi sehari-hari. Hal ini menunjukkan bahwa selama ini sumber belajar peserta didik masih terfokus pada guru dan buku tekstual, sedangkan lingkungan belum dimanfaatkan secara optimal (Jumadi, 2003).

Proses pembelajaran dituntut untuk selalu menyesuaikan dengan dinamika masyarakat. Artinya proses atau model serta teknik yang digunakan dalam pembelajaran semestinya menyesuaikan dengan tuntutan dan dinamika kehidupan di masyarakat lingkungan peserta didik (Muchit, 2007:4). Pembelajaran dengan pendekatan kontekstual menjembatani hal tersebut. Pembelajaran dikatakan menggunakan pendekatan kontekstual apabila materi pembelajaran tidak hanya tekstual tetapi dikaitkan dengan penerapan dalam kehidupan peserta didik di dalam lingkungan keluarga, masyarakat, alam sekitar bahkan dunia kerja sehingga menjadikan pembelajaran yang dilakukan lebih bermakna bagi peserta didik (Jumadi, 2003).

Pendekatan kontekstual telah banyak dikembangkan oleh para peneliti dengan berbagai macam tujuan, beberapa diantaranya adalah untuk meningkatkan kemampuan peserta didik dalam memecahkan masalah, berpikir kritis dan berpikir kreatif (Hidayat, 2010). Hal tersebut dikarenakan pendekatan kontekstual memiliki langkah-langkah pembelajaran yang mengembangkan kemandirian peserta didik, mengembangkan sifat ingin tahu, menciptakan masyarakat belajar, dan mengembangkan kemapuan analisis serta evaluasi peserta didik dalam proses pemecahan masalah (Wisudawati dan Sulistyowati, 2014:91). Akan tetapi pembelajaran berpendekatan kontekstual memiliki beberapa kelemahan, salah satunya yaitu bagi peserta didik yang tidak dapat mengikuti pembelajaran akan kesulitan karena tidak mendapatkan pengetahuan dan pengalaman yang sama dengan peserta didik lain (Dzaki, 2009). Hal tersebut dapat dijembatani dengan adanya bahan ajar mandiri untuk peserta didik.

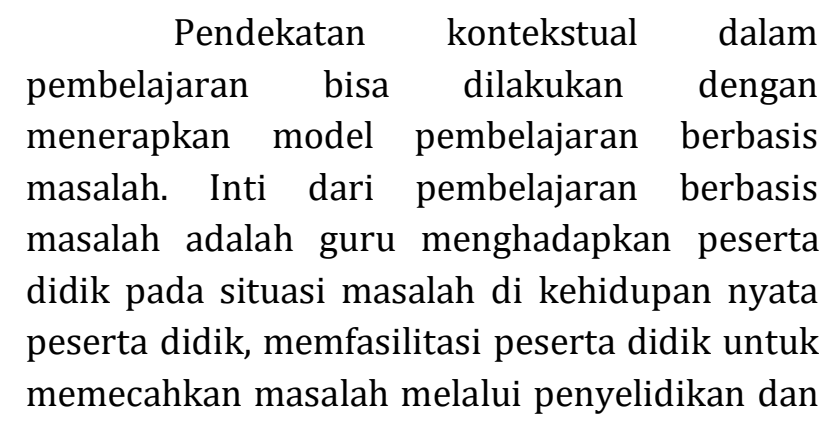

94

Copyright (C) 2019 JEC | ISSN 2715-3029 (p) 2685-4880 (e)

Volume 1, Nomor 2, 2019 
kerjasama, memfasilitasi terciptanya dialog antar peserta didik, dan merangsang peserta didik untuk menghasilkan pemecahan masalah (Jumadi, 2003). Beberapa prinsip tersebut dapat dijumpai dalam pembelajaran kontekstual Socioscientific Issues (SSI). Dikemukakan oleh Zeidler bahwa SSI merupakan pendekatan yang bertujuan untuk menstimulasi perkembangan intelektual, moral dan etika, serta kesadaran perihal hubungan sains dengan kehidupan sosial (Zeidler, dkk., 2005). Melalui pendekatan ini peserta didik dapat leluasa mengkontruksi pengetahuannya secara mandiri dengan difasilitasi oleh guru. Pembelajaran konstekstual dengan SSI mampu meningkatkan kemampuan berpikir kreatif peserta didik (Rahmawati, dkk., 2018).

Kelebihan yang terdapat pada pendekatan SSI dapat menjembatani kebutuhan peserta didik akan bahan ajar yang mengaitkan pembelajaran dengan kehidupan. Seperti yang diungkapkan oleh Suharyadi dkk bahwa bahan ajar instruksional yang terdapat di sekolah belum mengaitkan materi pembelajaran dengan kehidupan sosial peserta didik (Fibonacci dan Sudarmin, 2014). Pengembangan bahan ajar modul Socio-scientific Issues diharapkan dapat membantu peserta didik dalam memahami ilmu kimia yang dipelajari secara kontekstual dan mampu mempengaruhi peserta didik dalam mengambil keputusan terhadap permasalahan sosial yang terjadi di lingkungan sekitarnya.

Hasil pengolahan angket yang diberikan kepada peserta didik menunjukkan bahwa sebanyak 58,9\% peserta didik kelas XI IPA MA Al-Irsyad Gajah menyatakan materi reaksi reduksi oksidasi adalah materi yang sulit. Kesulitan tersebut dikarenakan materi reaksi reduksi oksidasi dianggap sebagai materi yang abstrak dan tidak dekat dengan permasalahan sehari-hari peserta didik. Hal ini ditunjukkan oleh adanya $48,2 \%$ peserta didik yang menyatakan bahwa materi kimia yang dipelajari tidak berhubungan dengan kehidupan seharihari. Selain itu, terbatasnya jumlah buku kimia yang tersedia juga menyebabkan peserta didik kesulitan untuk belajar secara mandiri. Hasil wawancara yang dilakukan peneliti dengan guru kimia sejalan dengan pengakuan peserta didik bahwa pada materi reaksi reduksi oksidasi peserta didik seringkali mengalami kesulitan belajar. Berdasarkan permasalahan tersebut, peneliti ingin mengembangkan Modul Kimia Socio-scientific Issues materi Reaksi Reduksi Oksidasi dan Tata nama Senyawa.

\section{Metode Penelitian}

Penelitian ini merupakan jenis penelitian R\&D (Research and Development) yang akan menghasilkan produk berupa modul kimia Socio-scientific Issues (SSI) materi reaksi reduksi oksidasi dan tata nama senyawa. Model pengembangan yang digunakan dalam penelitian ini adalah model pengembangan ADDIE yang meliputi tahap Analyze, Design, Develop, Implement, dan Evaluate (Branch, 2009).

Penelitian ini dilaksanakan di MA AlIrsyad Gajah. Subjek penelitian ini adalah peserta didik kelas X MA Al-Irsyad Gajah peminatan ilmu alam. Uji coba kelas terbatas pada produk dilakukan dengan melibatkan 9 peserta didik yang diambil dari 3 peserta didik kelas atas, 3 peserta didik kelas sedang, dan 3 peserta didik kelas bawah.

Teknik analisis data merupakan proses atau cara untuk menganalisis data yang didapatkan setelah penelitian dilakukan. Teknik analisis data yang digunakan dalam penelitian ini meliputi:

Copyright (C) 2019 JEC | ISSN 2715-3029 (p) 2685-4880 (e) Volume 1, Nomor 2, 2019 
a. Uji Validitas Modul oleh Validator

Uji validitas dilaksanakan oleh dua orang ahli, yaitu ahli materi dan ahli meddia. Validasi ahli dilakukan dengan menggunakan instrumen lembar validasi modul yang telah disesuaikan dengan indikator dari BSNP (2014). Valid tidaknya modul ditentukan dari kecocokan hasil validasi empiris dengan kriteria validitas yang ditentukan. Instrumen validitas modul ditentukan dengan angket validasi menggunakan rating scale 5 . Jumlah total skor validasi kemudian dihitung prsentasenya denganvaliditas Aiken's V yang terdapat pada Azwar (2012) dengan rumus sebagai berikut:

$$
\begin{aligned}
& \mathrm{V}=\frac{\sum s}{[n(c-1)]} \\
& \mathrm{s}=\mathrm{r}-\mathrm{l}_{0}
\end{aligned}
$$

Setelah itu, nilai $\mathrm{V}$ yang sudah dihasilkan dikonversikan dalam bentuk tabel kriteria yang disajikan pada Tabel 1.
Tabel 1 Tabel Kriteria Kevalidan menurut Retnawati (2016)

\begin{tabular}{ccc}
\hline No & Indeks & Kevalidan \\
\hline 1. & $>0,8$ & Sangat valid \\
2. & $0,41-0,8$ & $\begin{array}{c}\text { Cukup valid } \\
\text { Kurang } \\
\text { valid }\end{array}$ \\
\hline
\end{tabular}

b. Analisis Data Angket Respon Peserta Didik

\begin{tabular}{|c|c|c|}
\hline No & $\begin{array}{c}\text { Kriteria } \\
\text { Validitas }\end{array}$ & Tingkat Validitas \\
\hline 1. & $\begin{array}{c}85,01 \%- \\
100 \%\end{array}$ & $\begin{array}{l}\text { Sangat valid, atau } \\
\text { dapat digunakan } \\
\text { tanpa revisi }\end{array}$ \\
\hline 2. & $\begin{array}{c}70,01 \%- \\
85 \%\end{array}$ & $\begin{array}{lr}\text { Cukup } & \text { valid, atau } \\
\text { dapat digunakan } \\
\text { namun } \\
\text { direvisi kecil }\end{array}$ \\
\hline 3. & $\begin{array}{c}50,01 \%- \\
70 \%\end{array}$ & $\begin{array}{l}\text { Kurang valid, } \\
\text { disarankan tidak } \\
\text { dipergunakan } \\
\text { karena perlu revisi } \\
\text { besar }\end{array}$ \\
\hline
\end{tabular}
Data yang diperoleh melalui angket respon peserta didik akan dianalisa dan diolah sehingga diperoleh presentase respon peserta didik terhadap modul kimia bermuatan karakter, sehingga dapat diketahui kelayakan modul tersebut. Rumus yang digunakan untuk menghitung presentase adalah sebagai berikut:

Presentase $=\frac{\text { jumlah skor yang diperoleh }}{\text { jumlah skor maksimal }} \times 100 \%$ Presentase yang dihasilkan dikonversikan dalam bentuk tabel kriteria yang disajikan pada Tabel 2.

Tabel 2 Konversi Tingkat Pencapaian Peserta didik (Akbar, 2013) 


$\begin{array}{ccc}\text { 4. } & 01,00 \%- & \text { Tidak valid atau } \\ 50,00 \% & \begin{array}{l}\text { tidak boleh } \\ \text { dipergunakan }\end{array}\end{array}$

c. Analisis Tingkat Keterbacaan Modul Analisis tingkat keterbacaan modul dilakukan melalui uji tes isian rumpang atau metode klos pada peserta didik. Instrument yang digunakan oleh peneliti adalah lembar uji berisi wacana yang telah mengalami penghilangan atau pelesapan pada kata tertentu (Jatmika, 2007). Peserta didik diminta untuk melengkapi kata yang telah dihilangkan kemudian dilakukan penyekoran dengan rumus berikut:

$$
\text { Skor }=\frac{\text { jumlah jawaban benar }}{\text { jumlah jawaban yang dilesapkan }} \times 100 \%
$$

Selanjutnya, pada skor akhir ditetapkan kategorisasi tingkat keterbacaannya dengan teknik klos menurut Rankin dan Culhane dalam Jatmika (2007) seperti pada Tabel 3.

\begin{tabular}{|c|c|c|c|}
\hline Tabel & $\begin{array}{l}\mathrm{Ka} \\
\mathrm{Ke}\end{array}$ & $\begin{array}{l}\text { gorisasi } \\
\text { cbacaan }\end{array}$ & \\
\hline \multicolumn{2}{|c|}{ Skor } & $\begin{array}{l}\text { Ting } \\
\text { Keterb }\end{array}$ & \\
\hline \multicolumn{2}{|c|}{ Skor tes $>60 \%$} & Tin & \\
\hline \multicolumn{2}{|c|}{ Skor tes $40 \%-60 \%$} & Sed & \\
\hline \multicolumn{2}{|c|}{ Skor tes $<40 \%$} & Ren & \\
\hline
\end{tabular}

\section{Hasil Penelitian dan Pembahasan}

\section{Validasi Ahli Materi dan Ahli Media}

Uji validasi ahli dalam penelitian ini dilakukan oleh validator ahli selaku penilai produk yang terdiri dari empat validator, yaitu validator 1 (V.1) dan validator 2 (V.2) yang merupakan validator ahli materi, validator 3 (V.3) dan validator 4 (V.4) sebagai validator ahli media. Uji validasi ahli dilakukan untuk mengetahui kualitas modul kimia socio-scientific issues (SSI) materi reaksi reduksi oksidasi yang dikembangkan. Uji validasi menggunakan instrument lembar validasi yang memuat beberapa aspek dan indikator yang telah ditentukan mengacu pada BNSP (2014). Hasil validasi produk dari ahli materi atau konten disajikan dalam Tabel 4 berikut:

Tabel 4 Hasil Validasi Ahli Materi

\begin{tabular}{llll}
\hline No. & Aspek Penilaian & V.1 & V.2 \\
\hline 1. & Kelayakan isi & 18 & 18 \\
2. & Teknik penyajian & 36 & 36 \\
3. & Kebahasaan kimia & 24 & 24 \\
4. & Orientasi k & 11 \\
& berkonteks & & \\
& socioscientific issues & \\
\hline
\end{tabular}

Sedangkan hasil validasi dari validator ahli media yang kemudian disebut Validator 3 (V.3) dan Validator 4 (V.4) diperoleh hasil seperti pada Tabel 5.

Tabel 5 Hasil Validasi Ahli Media

\begin{tabular}{|c|c|c|}
\hline Komponen & V.3 & V.4 \\
\hline \multicolumn{3}{|l|}{ Penyajian modul } \\
\hline Ukuran & 4 & 4 \\
\hline Tata letak konsisten & 4 & 3 \\
\hline \multicolumn{3}{|l|}{ Kualitas tampilan } \\
\hline $\begin{array}{l}\text { Tata letak kulit/ } \\
\text { cover buku }\end{array}$ & 4 & 4 \\
\hline $\begin{array}{l}\text { Tipografi } \\
\text { buku } \\
\text { Kegrafikan }\end{array}$ & 4 & 3 \\
\hline Ilustrasi cover buku & 3 & 4 \\
\hline $\begin{array}{l}\text { Unsur tata letak } \\
\text { harmonis }\end{array}$ & 4 & 4 \\
\hline Tipografi isi buku & 4 & 4 \\
\hline $\begin{array}{l}\text { Ilustrasi isi } \\
\text { menimbulkan daya } \\
\text { tarik }\end{array}$ & 3 & 4 \\
\hline
\end{tabular}


Berdasarkan hasil validasi modul dari validator ahli materi dan ahli media diperoleh data kualitas produk secara kuantitatif yang terangkum pada Gambar 1.

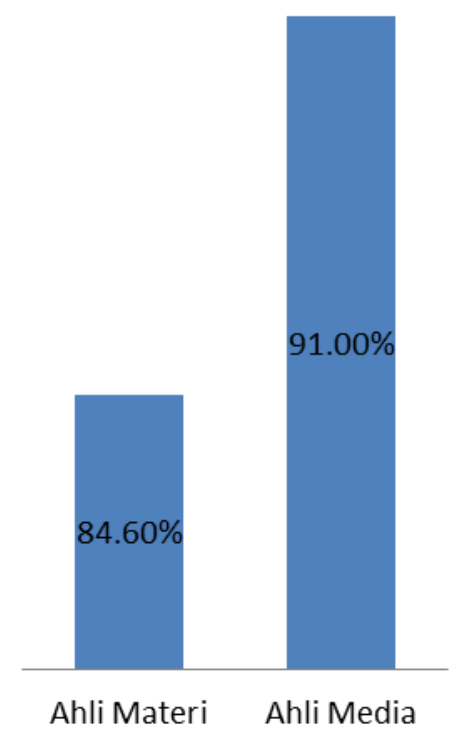

Gambar 1 Grafik Kualitas Penilaian Validator Ahli Materi dan Ahli Media

Berdasarkan Gambar 1 presentase hasil validasi rata-rata ahli materi adalah sebesar $84,60 \%$ dengan kategori sangat valid, dan untuk validasi rata-rata dari ahli media sebesar 91,00\% dengan kategori sangat valid. Berdasarkan hasil validasi oleh validator ahli materi dan ahli media modul kimia SSI yang dikembangkan layak untuk diujicobakan. Hasil validasi tersebut merupakan hasil akhir setelah dilakukan beberapa kali revisi pada modul.

Penilaian dilakukan dengan meninjau modul dari beberapa aspek dan indikator. Adapun penilaian pada tiap-tiap aspek dan indikator oleh ahli materi dirangkum dalam Gambar 2 sedangkan untuk penilaian oleh ahli media dirangkum dalam Gambar 3.

98

Copyright (C) 2019 JEC | ISSN 2715-3029 (p) 2685-4880 (e) Volume 1, Nomor 2, 2019

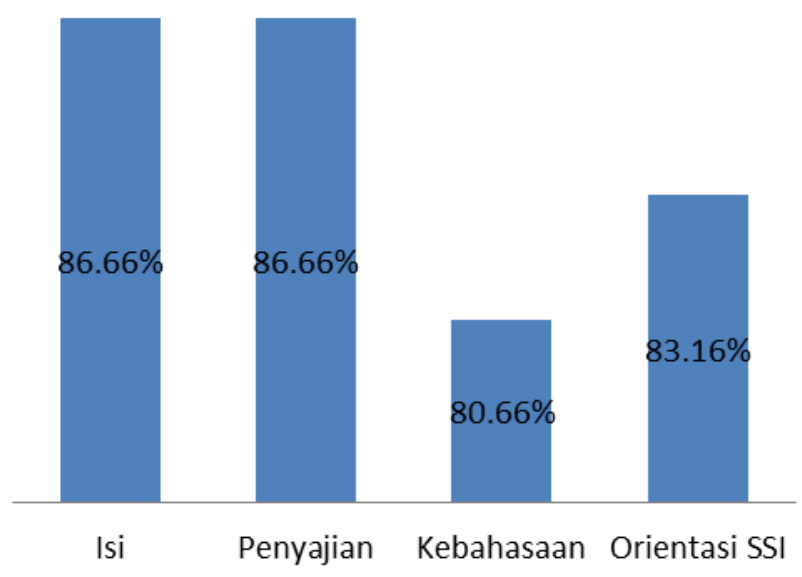

Gambar 2 Hasil Validasi Ahli Materi

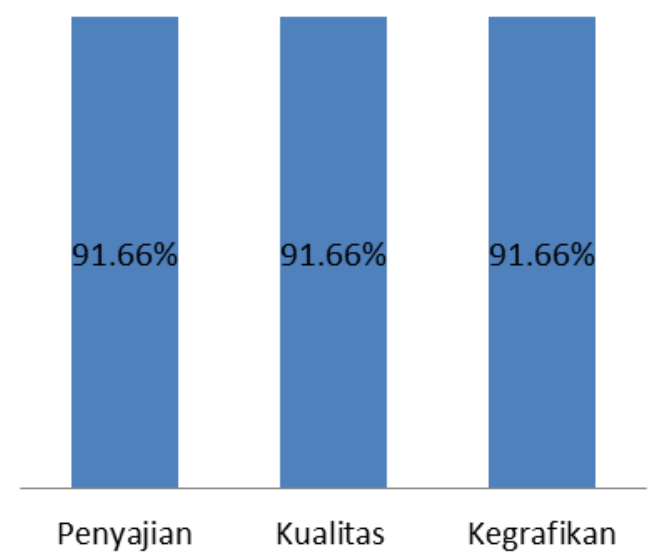

Gambar 3 Hasil Validasi Ahli Media

Berdasarkan Gambar $\mathbf{2}$ aspek penilaian yang materi meliputi kelayakan isi, kelayakan penyajian, kebahasaan, dan orientasi SSI yang termuat di dalam modul. Penilaian untuk kelayakan isi termasuk dalam kategori sangat valid. Kelayakan isi mencakup aspek kelengkapan materi, keakuratan fakta, keakuratan konsep, kemutakhiran contoh, aplikasi materi kimia. Aspek-aspek tersebut mengacu pada Badan Standar Nasional Pendidikan (BSNP). Sedangkan kelayakan 
penyajian meliputi aspek sistematika penulisan materi, keruntutan penyajian model pembelajaran, koherensi, kesesuaian ilustrasi, bahasa komunikatif, variasi penataan visual (penyajian), dan kelengkapan penyajian. Pada aspek penyajian hasil validasi menunjukkan hasil sangat valid. Aspek kebahasaan meliputi kesesuaian bahasa dengan tingkat perkembangan peserta didik, keterpahaman terhadap pesan, kemampuan memotivasi, ketepatan struktur kalimat, ketertautan antar kalimat atau alenia, dan konsistensi penggunaan istilah.

Penilaian untuk aspek kebahasaan oleh validator ahli media masuk dalam kategori sangat valid. Orientasi SSI pada modul mendapatkan nilai dengan kategori sangat valid yang penilaiannya meliputi pemilihan isu, penggunaan metode atau pendekatan pembelajaran SSI yang runtut, dan struktur rencana pembelajaran yang lengkap dan berkesinambungan.

Ahli materi sebagai validator juga memberikan saran perbaikan untuk modul SSI yang dikembangkan oleh peneliti. Adapun saran yang diberikan oleh validator ahli materi adalah sebagai berikut:

1) Memperbaiki beberapa tata tulis yang masih salah ketik ataupun belum sesuai dengan aturan ejaan yang disempurnakan (EYD).

2) Memperbaiki garis hubung pada peta konsep.

3) Memperbaiki judul isu pada subbab pertama pada modul.

4) Melengkapi keterangan volume dan waktu pada praktikum 1 dan 2 .

5) Melengkapi reaksi perkaratan besi.

6) Konsisten dalam penggunaan istilah alcohol detector.

7) Menyederhanakan penjelasan pada poin daya ikat atom dan muatan atom pada molekul kovalen.

8) Memperbaiki data pada isu gas rumah kaca dalam latihan 3.
Pada Gambar 3 hasil validasi ahli media pada aspek penyajian masuk dalam kategori sangat valid yang mencakup aspek ukuran dan tata letaknya. Untuk aspek kualitas tampilan validator juga memberikan nilai dengan kategori sangat valid dengan penilaian yang meliputi aspek penataan cover modul dan tipografinya. Kegrafikan modul mendapat nilai dengan kategori yang sama yaitu sangat valid dengan aspek penilaian tata letak dan pemilihan ilustrasi yang menarik.

\section{Uji Kelas Terbatas}

Uji kelas terbatas untuk modul kimia socio-scientific issues materi reaksi reduksi oksidasi dilakukan pada tahap implementasi dalam serangkaian tahapan penelitian pengembangan dengan model ADDIE. Uji lapangan atau uji coba produk dilakukan secara terbatas pada kelas kecil yang terdiri dari 9 peserta didik di kelas X MIA 2 MA Al-Irsyad Gajah. Tahapan ini dilakukan untuk mengetahui keterlaksanaan modul yang telah dikembangkan dan telah divalidasi oleh para validator atau ahli.

Berdasarkan hasil angket analisis kebutuhan dan wawancara yang dilakukan oleh peneliti, didapatkan fakta bahwa sebanyak $58,2 \%$ peserta didik mengalami kesulitan belajar kimia pada materi reaksi reduksi dan oksidasi, karena bagi peserta didik materi tersebut hanya membahas tentang persamaan reaksi dengan contoh penerapan yang sangat singkat serta belum mengaitkan materi yang dipelajari dengan konteks dunia nyata atau permasalahan yang dihadapi dalam keseharian. Hal ini ditunjukkan oleh adanya 48,2\% peserta didik yang menyatakan bahwa materi kimia yang dipelajari tidak berhubungan dengan kehidupan sehari-hari. Selain itu, terbatasnya jumlah buku kimia yang tersedia juga menyebabkan peserta didik kesulitan untuk belajar secara mandiri. Hasil wawancara yang dilakukan peneliti dengan guru kimia sejalan dengan pengakuan peserta didik bahwa pada materi reaksi reduksi oksidasi peserta didik seringkali mengalami kesulitan belajar. 
Salah satu cara yang dapat dilakukan supaya materi pembelajaran dapat terkait dengan konteks dunia nyata peserta didik adalah dengan penggunaan bahan ajar berbasis socio-scientific issues (SSI). Hal tersebut karena SSI merupakan pendekatan yang bertujuan untuk menstimulasi perkembangan intelektual, moral dan etika, serta kesadaran perihal hubungan sains dengan kehidupan sosial (Zeidler,dkk.,2005). Penggunaan SSI diharapkan dapat memicu kesadaran pada peserta didik sesuai dengan prinsip moral yang mendasar yang berhubungan langsung dengan kehidupan mereka. Melalui pendekatan SSI peserta didik dapat dengan leluasa mengkonstruksi pengetahuannya secara mandiri dengan difasilitasi oleh guru. Kelebihan yang terdapat pada pendekatan SSI ini dapat menjembatani kebutuhan peserta didik akan bahan ajar yang mengaitkan pembelajaran dengan kehidupan. Widhy, Nurohman, dan Wibowo (2013) melakukan penelitian tentang "Model Integrated Science Berbasis Socio Scientific Issues untuk Mengembangkan Thingking Skills untuk Mewujudkan 21st Century Skills". Penelitian tersebut membahas tentang pengembangan produk berupa silabus, RPP, LKS, dan Modul. Terdapat 4 tema yang diangkat, yaitu erupsi gunung berapi, zat aditif dalam makanan, pengelolaan sampah, dan pengelolaan limbah pabrik. Hasil penelitian menunjukkan bahwa penggunaan pendekatan SSI dapat mengembangkan keterampilan berpikir kritis peserta didik. Akan tetapi produk yang dikembangkan masih terbatas pada jenjang pendidikan sekolah menengah pertama, sedangkan kemampuan berinovasi, berpikir kreatif, pemecahan masalah, berpikir kritis, dan kemampuan dalam mengambil keputusan pada peserta didik perlu terus dikembangkan (Zubaidah, 2016).

Berbeda dengan Purwanti, Nurohman, dan Wibowo (2013) peneliti mengembangkan modul kimia SSI pada materi jenjang pendidikan
SLTA yang keseluruhan isu sosial ilmiahnya dapat diklarifikasi melalui praktikum di laboratorium. Hal ini dilakukan supaya pembelajaran yang berlangsung merupakan pembelajaran yang efektif dengan memanfaatkan sarana dan prasarana pendidikan yang tersedia secara optimal. Pembelajaran SSI yang dimuat didalam modul memiliki tahapan-tahapan yaitu pendekatan dan analisis masalah, klarifikasi melalui praktikum, melanjutkan isu sosial ilmiah, diskusi dan evaluasi, serta metarefleksi. Keseluruhan tahapan dimuat baik dalam modul maupun dalam pelaksanaan pembelajaran.

Kegiatan pembelajaran dimulai dengan mempersilahkan peserta didik untuk membaca permasalahan korosi pada jembatan Howrah, India. Peneliti mempersilahkan peserta didik untuk melakukan praktikum setelah peserta didik memahami langkah kerja pada praktikum 1. Setelah praktikum selesai dan dilakukan pengamatan, peneliti melakukan wawancara kepada pesera didik. Berdasarkan hasil wawancara dapat diketahui bahwa peserta didik dapat mengklarifikasi faktor-faktor penyebab korosi pada Jembatan Howrah melalui praktikum yang dilakukan.

Kemudian peneliti memandu peserta didik untuk mendiskusikan pertanyaan yang terdapat pada tahapan diskusi dan evaluasi untuk dijawab berdasarkan informasi yang dimiliki oleh peserta didik dan hasil pengamatan yang telah dilakukan. Di tengah-tengah kegiatan diskusi peneliti menanyakan hambatan yang dialami peserta didik. Pada bagian ini peserta didik dipersilahkan menyampaikan hasil diskusi kelompoknya di depan kelas dan saling menanggapi.

Berdasarkan dialog antara peneliti dan peserta didik tampak adanya ketertarikan pada peserta didik dalam mengikuti pembelajaran 
dengan modul SSI yang dikembangkan. Setelah diskusi dan evaluasi peserta didik diajak untuk merefleksikan serangkaian tahapan pembelajaran yang dilakukan pada rubik metarefleksi kemudian masuk pada penyampaian materi oleh peneliti. Pada tahapan metarefleksi peneliti meminta peserta didik untuk menuliskan pendapat pribadinya terkait pembelajaran yang telah berlangsung. Pada tanggapan yang ditulis peserta didik, 7 dari 9 peserta didik mengaku tertarik dengan materi reaksi reduksi oksidasi dan tata nama senyawa yang terdapat pada modul, dan mengaku bahwa pembahasan korosi pada jembatan Howrah selama pembelajaran berlangsung dapat mempengaruhi perilaku peserta didik untuk menjaga kesehatan dan lingkungan sekitar, hal ini sesuai dengan Tujuan pembelajaran SSI yang diungkapkan oleh Zeidler bahwa pembelajaran SSI bertujuan untuk menstimulasi perkembangan intelektual, moral, dan etika pada peserta didik (Zeidler,dkk., 2005) seperti pada penuturan peserta didik berikut ini:

\section{Peserta didik 1}

"Tertarik, karena bisa menambah wawasan. Mempengaruhi perilaku saya, karena sudah mengetahui akibat dari perilaku hidup tidak sehat seperti meludah sembarangan"

\section{Peserta didik 2}

“Tertarik, karena reaksi reduksi oksidasi banyak terdapat pada kehidupan kita sehari-hari dan agar kita tahu cara mengatasi dan menanggulangi masalah korosi setelah mempelajari materi ini. Setelah mengetahui hal tersebut saya lebih tau, dan menjaga kesehatan dan memperhatikan lingkungan sekitar agar tidak terjadi hal negatif"

Sedangkan 2 dari 9 peserta didik menyatakan tidak terlalu tertarik dengan pembelajaran SSI yang berlangsung. Tanggapan peserta didik dapat dilihat pada penuturan peserta didik berikut ini:

\section{Peserta didik 3}

"Tidak terlalu tertarik, InsyaAllah bisa. reaksi redoks adalah reaksi yang dipengaruhi oleh oksigen dan air. Reaksi redoks juga dapat dikatakan sebagai perkaratan. Dan benda-benda yang mengalami perkaratan akan hancur karena terkikis sedikit demi sedikit."

\section{Peserta didik 4}

"Tidak terlalu tertarik, Insyaallah bisa. Reaksi redoks merupakan reaksi yang dipengaruhi oleh adanya oksigen dan air juga mengubah besi menjadi berkarat, sehingga besi tersebut dapat sewaktu-waktu akan hancur."

Pembelajaran dilanjutkan dengan pemaparan konsep reaksi reduksi oksidasi oleh peneliti hingga selesai. Pembelajaran ditutup dengan menyimpulkan pembelajaran yang telah dilakukan. Peneliti juga pengajak peserta didik untuk mengerjakan soal tantangan yang terdapat pada modul. Pembelajaran kembali diakhiri dengan metarefleksi untuk menyimpulkan uraian materi pembelajaran yang telah disampaikan oleh peneliti. Metarefleksi dilakukan dengan mengajak peserta didik menjawab soal uraian singkat yang tersedia pada rubrik metarefleksi. Kemudian peserta didik diberi tugas untuk mengerjakan latihan 1 bersama kelompok untuk dikumpulkan pada pertemuan selanjutnya.

Peneliti melakukan wawancara terhadap 1 dari 2 peserta didik yang menyatakan tidak terlalu tertarik dengan pembelajaran menggunakan modul SSI.

Berdasarkan hasil wawancara didapatkan bahwa peserta didik 3 mengalami kesulitan dalam mencari alternatif pemecahan masalah untuk permasalahan yang disajikan. Peserta didik 3 mengaku tidak hafal dengan penulisan reaksi kimia dari peristiwa korosi yang terdapat pada permasalahan jembatan Howrah ketika harus mengisi kolom pertanyaan 
pada tahap diskusi dan evaluasi. Peneliti mengarahkan peserta didik untuk membaca uraian materi supaya peserta didik memiliki gambaran terhadap konsep reaksi reduksi oksidasi yang ditinjau dari penggabungan dan pelepasan oksigen, serta mempelajari reaksi kimia yang terjadi pada peristiwa korosi.

Pembelajaran dengan modul kimia SSI dilakukan sampai semua subbab dalam materi reaksi reduksi oksidasi dan tata nama selesai. Pada akhir pembelajaran materi reaksi reduksi oksidasi peneliti membagikan angket respon peserta didik dan melakukan wawancara terhadap peserta didik. berdasarkan hasil wawancara peserta didik mengaku bahwa pembelajaran dengan pendekatan socioscientific issues ini merupakan hal yang baru bagi mereka karena selama ini mereka belum pernah diajak untuk membedah suatu permasalahan sosial yang berkaitan dengan materi yang dipelajari.

Adanya kegiatan praktikum membuat peserta didik menjadi tertarik mengikuti proses pembelajaran. Ketertarikan peserta didik dapat dilihat dari kesungguhan peserta didik saat melakukan praktikum di dalam laboratorium, maupun saat peserta didik melakukan pengamatan di hari-hari selanjutnya. Hasil pengamatan yang diperoleh oleh peserta didik kemudian didiskusikan untuk menjawab pertanyaan pada tahapan diskusi dan evaluasi.

Tabel 6 Nilai Pretest dan Post test Peserta Didik

\begin{tabular}{ccc}
\hline $\begin{array}{c}\text { Peserta } \\
\text { Didik }\end{array}$ & $\begin{array}{c}\text { Nilai } \\
\text { Pretest }\end{array}$ & $\begin{array}{c}\text { Nilai } \\
\text { Posttest }\end{array}$ \\
\hline $\mathbf{1}$ & 60 & 88,5 \\
$\mathbf{2}$ & 34 & 85 \\
$\mathbf{3}$ & 32,5 & 90,5 \\
$\mathbf{4}$ & 30 & 75 \\
$\mathbf{5}$ & 39 & 72,5 \\
$\mathbf{6}$ & 32,5 & 75 \\
$\mathbf{7}$ & 29 & 54 \\
$\mathbf{8}$ & 28,5 & 60 \\
\hline
\end{tabular}

102

Copyright (C) 2019 JEC | ISSN 2715-3029 (p) 2685-4880 (e)

Volume 1, Nomor 2, 2019

\begin{tabular}{lll}
\hline 9 & 25 & 75 \\
\hline
\end{tabular}

Berdasarkan Tabel 6 dapat diketahui bahwa pembelajaran dengan menggunakan modul socio-scientific issues dapat meningkatkan kemampuan kognitif pada peserta didik. Hal tersebut menunjukkan bahwa modul socioscientific issues yang dikembangkan oleh peneliti dapat digunakan dalam pembelajaran kimia materi reaksi reduksi dan oksidasi. Sedangkan resume untuk hasil angket respon peserta didik dapat dilihat pada Gambar 4.

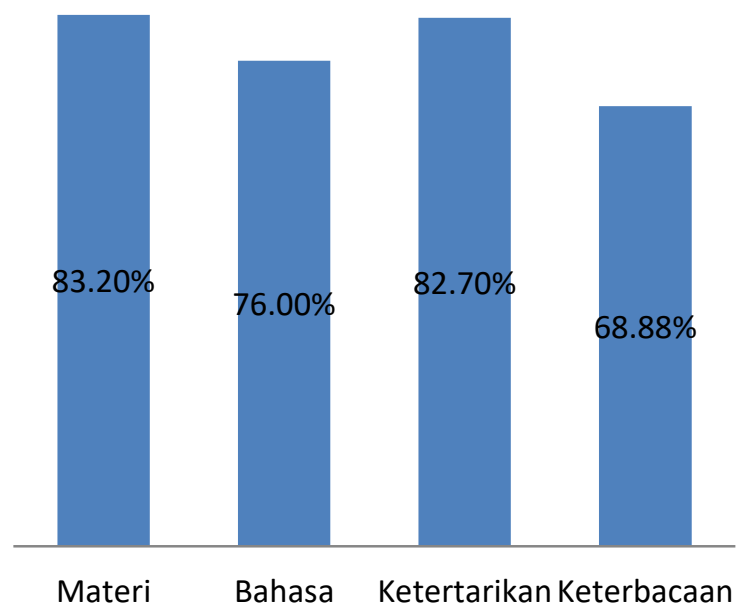

Gambar 4 Hasil Respon Peserta didik

Pada Gambar 4 memuat respon peserta didik yang di tinjau dari aspek materi, bahasa, ketertarikan, dan uji keteracaan. Dari respon peserta didik didapatkan bahwa modul kimia yang dikembangkan mendapatkan penilaian dengan kategori cukup valid pada aspek materi dengan skor 83,20 \%, mendapatkan kategori cukup valid pada aspek kebahasaan dengan skor 76,11\%, dan untuk aspek ketertarikan terhadap modul didapatkan skor $82,77 \%$ dengan kategori cukup valid. 
Uji keterbacaan modul dilakukan peneliti dengan membagikan tes isian rumpang (klos) pada peserta didik untuk mengetahui tingkat keterbacaan modul. Hasil dari perhitungan rata-rata skor yang didapatkan adalah sebesar 68,88\%. Berdasarkan Tabel 3 tentang kategorisasi tingkat keterbacaan, skor yang didapatkan termasuk dalam kategori tinggi. Menurut hasil tersebut dapat diketahui bahwa modul yang dikembangkan memiliki tingkat keterbacaan tinggi yang berarti bahwa wacana yang dimuat di dalam modul sudah sesuai dengan tingkat perkembangan peserta didik sebagai pengguna modul.

Adanya modul socio-scientific issues (SII) yang dikembangkan telah manambah jumlah modul atau bahan ajar yang sesuai dengan kurikulum 2013 di MA Al-Irsyad Gajah. Modul SSI yang dikembangkan manjadi variasi bahan ajar baru yang dapat digunakan oleh guru dan peserta didik dalam pembelajaran kimia materi reaksi reduksi oksidasi baik secara mandiri maupun kolektif. Pembelajaran kimia yang dilakukan pada kelas terbatas memperlihatkan adanya perubahan persepsi pada peserta didik yang semula menganggap mata pelajaran kimia tidak dekat dengan kehidupan menjadi beranggapan bahwa mata pelajaran kimia dekat dengan kehidupan, hal ini ditunjukkan oleh pengakuan peserta didik yang mengaku menjadi lebih peduli terhadap kesehatan dan lingkungan setelah mengikuti pembelajaran dengan modul kimia SSI. Akan tetapi modul SSI yang dikembangkan belum dapat sepenuhnya mengubah anggapan peserta didik perihal materi reaksi reduksi oksidasi yang dianggap sulit, hal ini ditunjukkan dengan adanya 2 dari 9 peserta didik yang mengaku tidak terlalu tertarik dengan pembelajaran dan masih mengalami kesulitan dalam menentukan jalan keluar dari permasalahan yang dibahas dalam pembelajaran.

\section{Simpulan dan Saran}

Simpulan

Berdasarkan hasil pengembangan dan uji coba kelas terbatas pada tahap implementasi dapat ditarik kesimpulan sebagai berikut:

1. Karakteristik modul kimia socio-scientific issues materi reaksi reduksi oksidasi adalah sebagai berikut:

a. Tahapan pembelajaran berbasis socioscientific issues (SSI) pada modul disusun secara runtut sehingga tujuan pembelajaran dapat tercapai. Tahapan yang dimuat antara lain: 1) pendekatan dan analisis masalah, 2) klarifikasi melalui praktikum, 3) melanjutkan isu sosial ilmiah, 4) diskusi dan evaluasi, dan 5) metarefleksi.

b. Seluruh permasalahan sosial yang terdapat di dalam modul dapat diklarifikasi melalui kegiatan praktikum.

2. Kualitas modul kimia socio-scientific issues materi reaksi reduksi oksidasi berdasarkan penilaian validator ahli materi tergolong pada kategori Sangat baik (SB) dengan persentase $88,50 \%$, sedangkan kualitas modul peserta didik berdasarkan penilaian validator ahli media tergolong pada kategori Sangat baik (SB) dengan persentase $93,75 \%$ sehingga dapat disimpulkan modul kimia socio-scientific issues materi reaksi reduksi oksidasi layak diuji cobakan.

3. Kualitas modul kimia socio-scientific issues materi reaksi reduksi oksidasi berdasarkan respon peserta didik didapatkan bahwa modul kimia yang dikembangkan mendapatkan penilaian dengan kategori baik (B) pada aspek materi dengan ratarata keidealan sebesar 82,77\%, kategori baik (B) pada aspek kebahasaan dengan rata-rata keidealan 76,11\%, dan kategori baik (B) untuk aspek ketertarikan terhadap modul dengan rata-rata keidealan sebesar $82,77 \%$. 
Berdasarkan hasil uji kualitas modul dengan metode validasi oleh ahli, respon peserta didik dalam uji kelas terbatas dan uji keterbacaan dapat disimpulkan bahwa modul kimia socio-scientific issues materi reaksi reduksi oksidasi layak digunakan dan diuji lebih lanjut untuk diimplementasikan pada kelas besar guna mengetahui efektivitas modul baik terhadap minat belajar maupun hasil belajar peserta didik.

Saran

Berdasarkan hasil penelitian pengembangan modul kimia socio-scientific issues materi reaksi reduksi oksidasi, peneliti memberikan saran sebagai berikut:

1. Modul kimia socio-scientific issues materi reaksi reduksi oksidasi diimplementasikan pada kelas besar.

2. Perlu dilakukan penelitian lebih lanjut pada modul kimia socio-scientific issues materi reaksi reduksi oksidasi untuk mengetahui efektivitas penggunaan modul terhadap variabel-variabel seperti minat belajar peserta didik, kemampuan berpikir kritis, hasil belajar dan keterampilan kerja laboratorium pada peserta didik.

3. Isu sosial yang dipilih sebaiknya adalah isuisu yang penting dan dekat dengan lingkungan peserta didik, atau isu yang menjadikan seluruh peserta didik tertarik untuk mengikuti pembelajaran.

Perlu dilakukan pengembangan lebih lanjut terhadap modul kimia socio-scientific issues dengan materi pokok yang berbeda dan tingkat kelas yang berbeda supaya bahan ajar yang memuat pembelajaran kontekstual terus bertambah

\section{Daftar Pustaka}

Abidin, N. 2018. Pengembangan Modul Kimia Berbasis Integrasi Islam-Sains pada Materi Struktur Atom dan Sistem

104

Copyright (C) 2019 JEC | ISSN 2715-3029 (p) 2685-4880 (e)

Volume 1, Nomor 2, 2019
Periodik Unsur Kelas X SMA/MA. Skripsi. Semarang: Fakultas Sains dan Teknologi UIN Walisongo Semarang.

Aisyah. 2007. Penerapan Metode Pembelajaran Portofolio dengan Pendekatan Sains, Lingkungan, Teknologi dan Masyarakat (SETS) pada Mata Pelajaran Ekonomi Kelas X SMA Negeri 15 Semarang. Skripsi. Semarang: Universitas Negeri Semarang.

Akbar, S. 2016. Instrumen Perangkat Pembelajaran. Bandung: PT Remaja Rosdakarya.

Branch, R.M. 2009. Instructional Design: The ADDIE Approach. Department of Educational Psychology and Instructional Technology University of Georgia: Springer Science Business Media.

Dzaki. 2009. Kelebihan dan Kelemahan Pembelajaran CTL, diakses dari laman web www.sekolahdasar.net tanggal 15 Januari 2019.

Erifal. 2010. Pengembangan Modul Pemecahan Masalah pada Pembelajaran Geometri Di SMA. Skripsi. Palembang: FKIP UNSRI.

Fibonacci, A. \& Sudarmin. 2014. Development Fun-Chem Learning Materials Integrated Socio-Science Issues to Increase Students Scientific Literacy. International Journal of Science and Research (IJSR), 3 (11), 708-713.

Hidayat, R. 2010. Pembelajaran Kontekstual dengan Strategi REACT dalam Upaya Pengembangan Kemampuan Pemecahan Masalah, Berpikir Kritis, dan Berpikir Kreatif Matematis Mahasiiswa Bidang Bisnis. Skripsi. Bandung: Universitas Pendidikan Indonesia. 
Holbrook, J. 2005. Making Chemistry Teaching Relevant. Paper. Chemical Education International. Vol. 6 No. 1.

Hosnan, M. 2014. Pendekatan Saintifik dan Kontekstual dalam Pembelajaran Abad 21. Bogor: Gahlia Indonesia.

Iswara, W. dan tim dosen LPTK. 2008. Penulisan Modul. Jakarta: Direktorat Kependidikan Direktorat Jenderal Peningkatan Mutu Pendidik dan Tenaga Kependidikan Departemen Pendidikan Nasional.

Jatmika, W. 2007. Tingkat Keterbacaan Wacana Sains dengan Teknik Klos. Jurnal Sosioteknologi, 6 (10): 197-198.

Jumadi. 2003. Pembelajaran Kontekstual dan Implementasinya. Makalah pada Workshop Sosialisasi dan Implementasi Kurikulum 2004 Madrasah Aliyah DIY, Jateng, Kalsel di FMIPA UNY Tahun 2003.

Lindahl, B. dkk. 2011. Socio-scientific Issues - A Way to Improve Students Interest And Learning?. US-China Education Review. B 3 (2011): 342-347.

Muslich, Mansur. 2009. KTSP Pembelajaran Berbasis Kompetensi dan Kontekstual. Jakart: Bumi Aksara.

Poedjiadi, Anna. 2005. Sains Teknologi Masyarakat: Model Pembelajaran Kontekstual Bermuatan Nilai. Bandung: Remaja Rosdakkarya

Pratiwi, Y.N., S. Rahayu, F. Fajaroh. 2016. Socioscientific Issues (SSI) In Reaction Rates Effect On The Critical Thinking Skills Of High School Students. Jurnal Pendidikan IPA Indonesia. 5(2): 164-170.

Putri, Dwi Susanti. 2016. Pengembangan Modul Beroirentasi Unity of Sciences dengan Pendekatan Contextual Teaching and Learning pada Materi Termokimia. Skripsi. Semarang: Fakultas Sains dan Teknologi UIN Walisongo Semarang.
Reguli, J. 2016. Controversial Socio-scientific Issues in Chemistry Teachers' Education. Paper, Slovakia: Department of Chemistry, Faculty of Education Trnava University.

Sanjaya, Wina. 2006. Strategi Pembelajaran Berorientasi Standar Proses Pendidikan. Jakarta: Kencana Prenada media.

Sastromiharjo, A. 2008. Media dan Sumber Pembelajaran. Prosiding. Disampaikan Pada Pendidikan Dan Pelatihan Profesi Guru Sekolah Menengah Pertama. Bandung: Universitas Pendidikan Indonesia.

Sugiyanto. 2008. Modul PLPG (Model-Model Pembelajaran Inovatif). Surakarta: Panitia Sertifikasi Guru Rayon 13

Sugiyono. 2016. Metode Penelitian Pendidikan (Pendekatan Kuantitatif, Kualitatif, dan $R \& D)$. Bandung: Alfabeta.

Susilana, R., Cepi R. 2008. Media Pembelajaran. Bandung: CV. Wacana Prima.

Syamsudin, A.M. 2005. Psikologi Kependidikan: Perangkat Sistem Pengajaran Modul. Bandung: Remaja Rosda Karya.

Widia, R., J. Ratnasari, Suhendar. 2018. Pengaruh Pendekatan Pembelajaran Socioscientific Issues Terhadap Kemampuan Berpikir Kreatif Peserta Didik. Jurnal Pelita Pendidikan. Vol. 6 No. 1: 125.

Widoyoko, E.P. 2010. Evaluasi Program Pembelajaran. Yogyakarta: Pustaka Pelajar.

Widoyoko, E.P. 2012. Teknik Penyusunan Instrumen Penelitian. Yogyakarta: Pustaka Pelajar.

Winataputra, Udin S. 2001. Strategi Belajar Mengajar IPA. Jakarta: Universitas Terbuka dalam https://www.wawasanpendidikan.com diakses tanggal 25 januari 2019 pukul 11:27 WIB. 
Wisudawati, A.W., Eka S. 2014. Metodologi Pembelajaran IPA. Jakarta: Bumi Aksara.

Zeidler, D.L. dkk, 2005. BeyondSTS: A ResearchBased Framework for Socioscientific Issues Education. Diunduh di https://onlinelibrary.wiley.com/ tanggal 9 Oktober 2017.

Zubaidah, S. 2016. Keterampilan Abad Ke-21: Keterampilan yang Diajarkan Melalui Pembelajaran. Paper. Malang: Universitas Negeri Malang. 